\title{
Municipal solid waste management in Malaysia: practices and challenges.
}

\begin{abstract}
Rapid economic development and population growth, inadequate infrastructure and expertise, and land scarcity make the management of municipal solid waste become one of Malaysia's most critical environmental issues. The study is aimed at evaluating the generation, characteristics, and management of solid waste in Malaysia based on published information. In general, the per capita generation rate is about $0.5-0.8 \mathrm{~kg} /$ person/day in which domestic waste is the primary source. Currently, solid waste is managed by the Ministry of Housing and Local Government, with the participation of the private sector. A new institutional and legislation framework has been structured with the objectives to establish a holistic, integrated, and cost-effective solid waste management system, with an emphasis on environmental protection and public health. Therefore, the hierarchy of solid waste management has given the highest priority to source reduction through $3 \mathrm{R}$, intermediate treatment and final disposal.
\end{abstract}

Keyword: Municipal solid waste. 